\title{
Common Instruments and Strategies for Regional Economic Integration of Transnational Corporations
}

\author{
Sai Zou ${ }^{1, a}$, Jiaxiang Ye ${ }^{2, b}$ \\ ${ }^{1}$. Adam business school (MSc management), University of Glasgow, Glasgow, Scotland, G12 8QQ \\ ${ }^{2}$ Durham business school (MSc Management (finance)), Durham University, Durham, United Kingdom, DH1, 3DE \\ a2273185010@qq.com \\ b491923583@qq.com
}

\begin{abstract}
With economic globalization sweeping through every country in the world, liberalized regional economic integration, financial globalization, product globalization, liberalized international trade, liberalized international investment is deeply impacting and affecting all countries in the world, bringing unprecedented prospects to the economies of all countries in the world, strong competition among nations, countries and countries, great changes in the world's micro economy and macro economy, and East Asia is one of the most dynamic economic regions in the world economy. This paper mainly studies the current situation of regional integration of transnational corporations in East Asia, after analyzing the intra-regional trade and comparison with the EU, NAFTA, it is found that the proportion of internal trade in East Asia has been higher than that of the North American Free Zone in the period of nearly 18 years, and has been nearly 17 percent higher by 2010. East Asian integration investment and market, East Asian trade integration shows typical characteristics of production and trade. Through the early literature study of East Asian integration, the basis of literature review in the past 15 years, combined with the use of interdisciplinary comprehensive analysis, the flexible use of micro-macroeconomic theory, regional economics and other disciplines and their research methods combined with empirical analysis, it is found that the development of regional economic integration of multinational corporations faces many difficulties, such as capital and technology external dependence, final consumer market external dependence, diversity of national strategies, lack of identity, etc. It is unsustainable to strengthen the ability of technology development and innovation to boost the economy through high investment and large-scale trade.
\end{abstract}

Keywords: TNC strategic alliance, economic integration, East Asia, international direct investment.

\section{INTRODUCTION}

With the deepening trend of regional economic integration of multinational corporations, regional economic integration organizations have also developed rapidly. In order to improve the level of economic development of the countries of the region, regional economic integration organizations are committed to reducing or removing trade and investment barriers, promoting the free movement of goods, technology, services and people within the region, and providing favourable conditions for enterprises in member countries to optimize the allocation of resources within the regional economy, thus bringing about the creative effects of trade and investment. The effect of regional economic integration has great attraction to international enterprises. Many international enterprises regard the development of regional integration market as an important strategy of international operation. After entering the $21 \mathrm{st}$ century, the pace of international operation of multinational enterprises has been greatly accelerated. More and more international enterprises not only rely on their own resources and skills to expand the global market, but also continue to expand the markets of various regional economies. In order to enhance the competitive advantage of the international market.

Many international scholars believe that the trade and investment effects of regional economic integration will directly affect the marketing performance of foreign enterprises entering the integrated market [1], and study this problem. It is helpful for multinational enterprises to find out the market opportunities and environmental threats that may be obtained into the integrated market [2]. The trade effect of regional economic integration of 
transnational corporations is the "customs union theory "put forward by the scholars concerned [3]. The customs union theory is the income generated by trade, minus the loss caused by trade transfer, and they use the method of partial equilibrium analysis to compare and explain productivity differences and differences between trade regions. The customs union produces two effects, one is trade transfer, that is, a country participates in the customs union, which turns from importing low-cost products from the outside world to buying high-cost products by members of the alliance; the second is the trade creation effect, that is, the high cost products of some countries in the customs union are replaced by low cost imports from another country [4].

By analyzing the meaning of the strategic alliance of transnational corporations and the meaning of economic integration, this paper discusses that international direct investment promotes the international division of labor among East Asian countries, especially the intra-industry division of labor, and promotes trade among the major economies of East Asia [5].

\section{PROPOSED METHOD}

\subsection{Definition of strategic alliances of transnational corporations}

The earliest multinational alliances originated in the 1970s Ford and Mazda auto industries in Japan, which formed a strategic alliance that globalised auto product development, sales, supply and so on, saving at least $\$ 3.5$ billion a year. With this initial strategic alliance formed, enterprises can through product development, product research, production and processing, sales and other services, in the form of mutual participation in shares and other forms of long-term cooperation, to achieve supply, and ultimately regional stability [7]. Global 500 multinational corporations occupy one third of the world's GDP and three quarters of global trade; the strategic alliance of multinational corporations refers to the cooperative relationship between two or more multinational corporations to achieve the same strategic goal together [8]. This alliance is an external partnership to enhance the business value of the enterprise, not through internal value-added. The strategic alliance of multinational companies has become the main form of entering the new international market and realizing the strategic goal of the rapid development of enterprises. In particular, capital-intensive industries are the main means to seek international competitiveness and strengthen internal competitive advantage [9]. The emergence of this kind of alliance has disintegrated the traditional market "dead and dead" competition mode, the arrival of the 21 st century, win-win has been our common goal.

Trade integration is a more comprehensive indicator of the trade interdependence of the two countries; it refers to the proportion of a country's total exports to a trading partner country and the proportion of the total imports of the trading partner country [10]. The greater the value, the closer the two countries are in trade. The formula for calculating trade union is as follows:

$$
T C D_{a b}=\left(X_{a b} / X_{a}\right) /\left(M_{b} / M W\right)
$$

$\mathrm{TCD}_{\mathrm{ab}}$ shows a trade union with $\mathrm{b}$ countries, $\mathrm{X}_{\mathrm{ab}}$ is a country's exports to $\mathrm{b}$ country.The $\mathrm{Xa}$ represents the total exports of a countries; the $\mathrm{Mb}$ represents the total imports of $b$ countries; the total world imports, if TCDab> the two countries are closely linked in trade; and if TCDabTCDab>1, the two countries are loosely linked in trade.

Marginal contributions:

$$
M=(p-b) x=m^{*} x
$$

Where $\mathrm{M}$ is marginal contribution; $\mathrm{p}$ is unit price of sales; $b$ is unit change Chen Ben; $m$ unit marginal contribution; $\mathrm{x}$ production and sales.Economic growth refers to the continuous increase of total output or per capita output in a certain period of time, which can be measured by economic growth rate. The measurement index generally selects gross national product and per capita gross national product, among which the key factor is the correction of per capita and price changes. According to the analysis, the formula of regional economic growth rate can be expressed as:

$$
g=G_{t}-G_{t-1} / G_{t-1}=\Delta G_{t} / G_{t-1}
$$

The $\mathrm{g}$ is the economic growth rate, Gt the GDP,Gt-1 of the $t$ year means that the GDP,Gt and GT- 1 of the year are both true and GDP, that is, the influence of prices on the GDP during the calculation period is deducted. The method of eliminating the influence of price often adopts GDP reduction index. In actual calculation, CPI is used to replace GDP reduction index.

\subsection{Meaning of economic integration}

In the 1950s ," economic integration "was first defined, and foreign scholars thought that two independent countries had economic and trade relations, which could be called economic integration. With the strategic alliance between the economies of various countries, the forms of economic integration were uneasy. Customs union refers to the elimination of tariffs and import restrictions between member countries in free trade zones, but because each country retains its own tariffs on non-member countries, the customs union is lower than the common market, which guarantees the free flow of factors of production; the economic alliance should combine the inhibition of the flow of products and factors of production with some degree of coordination of national economic policies. Its highest form is to construct an authority that transcends the state 
and decides to bind all member States. Some Chinese scholars define the regional economic integration of multinational corporations as the process of market integration between different economic subjects in order to form the acquisition of their own interests such as production, consumption, sales and trade. It includes the unified evolution from product market, factor market to economic policy. Economic integration is the combination of state and process, method and purpose. In general, regional economic integration of transnational corporations (TNCs) is an institutional arrangement in which developing countries, in order to adapt to the trend of economic globalization and trade integration, strengthen win-win economic cooperation within and outside the region based on the economic and trade rules of bilateral regional or multilateral cooperation in the light of their own economic development.

\section{EXPERIMENTS}

\subsection{Research content}

Based on theoretical analysis, literature review and clear definition of concepts, and guided by theoretical knowledge of relevant economic disciplines, and based on the study of East Asian trade integration, (East Asian trade and EULNAFTA comparison), East Asian investment integration, East Asian integration investment and market "two in the outside" discovery, the study found that East Asian regional trade and off-regional trade show a rapid growth situation; East Asian integration has actually exceeded the level of free trade area, customs union; as a regional economic group, East Asia not only depends on the US and Europe market in capital and technology, but also on the US and Europe market in the sales market of final products, forming a "two ends in the outside" pattern. The above research provides good support and reference for the formulation of regional economic integration strategy of multinational corporations in the future.

\subsection{Research methodology}

Through the early literature study of East Asian regional integration (trade integration, investment integration, etc.), relying on interdisciplinary comprehensive analysis, flexible use of micro-macroeconomic theory and other disciplines, using empirical research and analysis methods, this paper discusses the development and present situation of TNC trade and investment integration in East Asia. Since 1992, the proportion of regional trade volume in East Asia has exceeded the corresponding targets of the United States, Canada and Mexico, and by 2010, it has been nearly 17 points higher. It is found that the development of regional economic integration of TNCs is still facing many difficulties.

\section{DISCUSSION}

\subsection{East Asian trade integration}

\subsubsection{Intra-East Asian Trade and Comparison with EU、NAFTA}

In the mid-1980s, the appreciation of the yen prompted Japan to increase investment in Southeast Asian countries and the rapid rise of emerging economies in East Asia. At the same time, China also began the process of reform and opening up. East Asia's regional trade and off-regional trade are showing rapid growth. Although the share of intra-regional trade in East Asia is about a percentage point lower than that of the European Union, since 1992, the share of intra-regional trade in East Asia has exceeded the corresponding target of the United States, Canada and Mexico, except during the East Asian financial crisis. In the nearly 18-year period, the share of intra-regional trade in East Asia has been higher than that of the North American Free Zone, and by 2010 it has been nearly 17 hundred points higher. Although the proportion of internal trade in East Asia is lower than that of the European Union, it is roughly the same as that of the European Community in 1975-1990(see table 1). It can be seen that although East Asia has not been established for a long time, East Asia is already in fact.

Table 1.1992-2010 Share of intra-regional trade in total trade of major East Asian economies unit: \%

\begin{tabular}{|c|c|c|c|c|c|c|c|c|c|c|}
\hline & 1992 & 1994 & 1996 & 1998 & 2000 & 2002 & 2004 & 2006 & 2008 & 2010 \\
\hline ASEAN & 17.7 & 16.3 & 22.8 & 20.5 & 19.5 & 24.1 & 24.7 & 21.4 & 26.8 & 24.2 \\
\hline $\begin{array}{c}\text { North } \\
\text { American } \\
\text { Free Trade } \\
\text { Area }\end{array}$ & 36.2 & 39.9 & 40.8 & 45.3 & 46.7 & 47.6 & 44.3 & 45.2 & 40.1 & 43.2 \\
& 11.3 & 15.8 & 16.7 & 20.2 & 15.8 & 21.5 & 22.4 & 25.50 & 22.2 & 23.6 \\
\hline $\begin{array}{c}\text { China - } \\
\text { Kapan - } \\
\text { Korea }\end{array}$ & & & & & & & & & & \\
\hline
\end{tabular}




\begin{tabular}{|c|c|c|c|c|c|c|c|c|c|c|}
\hline $\begin{array}{c}10 \text { a East } \\
\text { Asia }\end{array}$ & 39.6 & 44.2 & 46.8 & 49.5 & 42.3 & 50.3 & 48.4 & 49.5 & 49.5 & 52.3 \\
\hline $\begin{array}{c}\text { EU } \\
15 / 25 / 27 \text { b }\end{array}$ & 64.4 & 67.1 & 60.5 & 66.4 & 64.2 & 66.1 & 67.8 & 66.7 & 64.3 & 65.8 \\
\hline
\end{tabular}

\subsubsection{Investment integration in East Asia}

Investment is an important part and important driving force of East Asian de facto integration. The beginning of East Asian integration in the middle of the decade was promoted by Japan's large-scale investment in Southeast Asian countries. International direct investment promotes the international division of labor among East Asian countries, especially within industries, and promotes trade among the major economies of East Asia, especially in intermediate products. To a large extent, the trade integration of East Asia is driven by investment integration. In East Asia and from outside the region, a worldwide production network system was established in East Asia, which made East Asia a global manufacturing base. The de facto integration of East Asia is not only trade integration, but also production integration. If the integration classification criteria and levels are determined according to the EU paradigm, East Asian integration has actually gone beyond the level of free trade area and customs union. International investment includes direct investment and indirect investment, which belongs to the category of capital market. Therefore, the main discussion here is the growth of international direct investment in East Asia.

Table 2.Countries of origin of FDI,

China ,1995-2010(regions) unit: \%

\begin{tabular}{|c|c|c|c|c|c|}
\hline & $\begin{array}{c}1995-1 \\
997\end{array}$ & $\begin{array}{c}1998-2 \\
009\end{array}$ & $\begin{array}{c}2000-2 \\
003\end{array}$ & $\begin{array}{c}2004-2 \\
007\end{array}$ & $\begin{array}{c}2008- \\
2010\end{array}$ \\
\hline $\begin{array}{c}\text { From } \\
\text { East } \\
\text { Asia }\end{array}$ & 80.09 & 73.53 & 65.5 & 58.59 & 56.53 \\
\hline $\begin{array}{c}\text { HK } \\
\text { and } \\
\text { Maca } \\
\text { o }\end{array}$ & 47.7 & 39.56 & 38.25 & 34.15 & 29.55 \\
\hline Japan & 13.65 & 15.6 & 9.86 & 8.56 & 6.56 \\
\hline $\begin{array}{c}\text { ASEA } \\
\mathrm{N}\end{array}$ & 16.59 & 8.56 & 3.25 & 4.89 & 5.19 \\
\hline EU & 5.69 & 8.98 & 8.56 & 7.89 & 6.68 \\
\hline $\begin{array}{c}\text { North } \\
\text { Ameri } \\
\text { ca }\end{array}$ & 5.66 & 7.58 & 7.89 & 6.59 & 6.57 \\
\hline $\begin{array}{c}\text { Taiwa } \\
\mathrm{n}\end{array}$ & 3.56 & 8.59 & 6.94 & 5.19 & 5.16 \\
\hline Virgin & 4.59 & 5.56 & 8.59 & 17.56 & 25.49 \\
\hline else & 8.59 & 6.47 & 12.0 & 11.26 & 11.59 \\
\hline
\end{tabular}

China is East Asia and the most attractive developing country in the world. Table 2 shows the countries of origin (regions) of China's actual foreign direct investment (FDI) from 1995 to 2010. In the middle of the decade, China's surplus came from East Asia, which has been declining in recent years, but still exceeded until 2010. An important source of foreign investment in China in recent years is the Virgin Islands, which has a large number of multinational headquarters and is a freer and more active financial center than Hong Kong. Because of the complexity of cross-border capital flows, there is no accurate data to distinguish between the main investors transferred to Chinese mainland via Virgin and Hong Kong and their country attributes. Comparatively speaking, more European and American companies invest Chinese mainland through the Virgin Islands, and of course some Asian companies, even a few domestic companies, transfer funds through the Virgin Islands to invest in the mainland. And through Hong Kong, an international capital "corridor" investment Chinese mainland capital, East Asian multinational companies are more than European and American multinational companies. Considering the complementary and countervailing effects of Virgin and Hong Kong, China's FDI half come from East Asia.

\subsection{East Asian Integration Investment and Markets "Two Out"}

As a regional economic group, East Asia not only depends on the US and Europe market in capital and technology, but also on the US and Europe market in the sales market of final products, forming a "two ends in the outside" pattern. As an important basis of East Asian fact, trade in East Asia is highly integrated, and the proportion of regional trade is more than 50 percentage points. However, intra-East Asian trade is dominated by intermediate products. As shown in Figure 1, the highest proportion of intra-East Asian trade products is that the proportion of very high, which is close to the proportion of Canadian trade products. As investment equipment, capital goods trade also has a certain proportion. The trade proportion of the first three kinds of products is higher than that of the final consumer goods, and the proportion of the trade of processed products and parts and components is about twice that of the final consumer goods trade. Trade integration in East Asia is characterized by typical "trade for production" characteristics. 


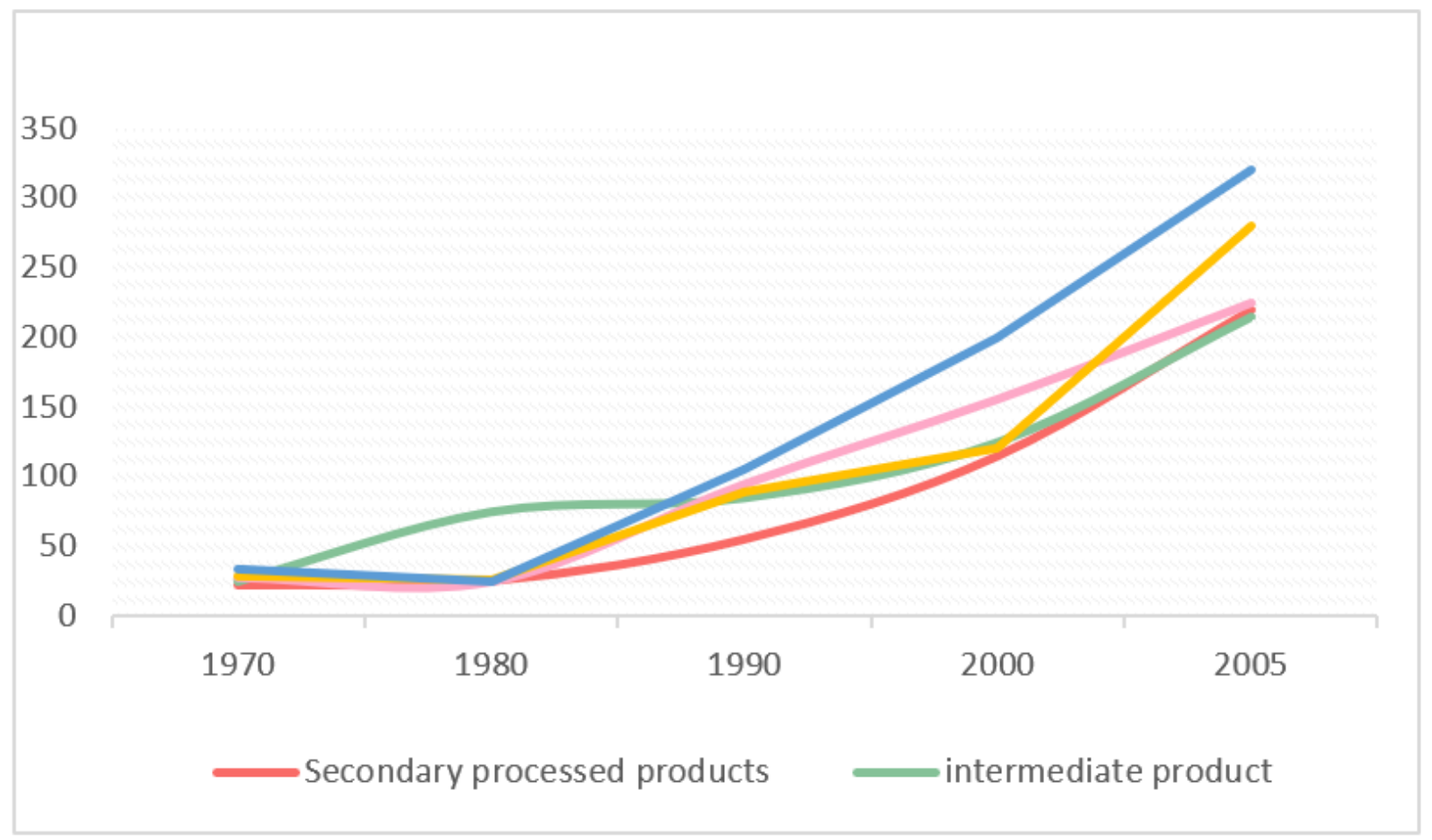

Figure 1.Product structure of intra-East Asian trade unit: million dollars

\section{CONCLUSIONS}

Japan, South Korea and China all lack original innovation, that is, the original innovation of science and technology has not been paid enough attention to, the emphasis of innovation is mainly on technological innovation, integrated innovation and "introduction, absorption, re-innovation ", while the original scientific innovation depends on the United States and Europe. During the Cold War, the United States and Europe gave preferential treatment to Korea's technology introduction and innovation for strategic interests. After the end of the Cold War, the protection of intellectual property rights in the United States and Europe became more and more strict, so the technological innovation of Japan and South Korea was restricted, and the dominant power of East Asian economic integration fell into the hands of European and American multinational corporations. In recent years, South Korea has made remarkable progress in technological innovation, but South Korea's basic science is weak and still in a relatively backward position in primitive innovation. Although China has a relatively complete discipline system of scientific research, the level of scientific innovation is low, and it is in a more backward situation in the transformation of technological achievements into productive forces.

As far as the regional economic integration of multinational corporations is concerned, many companies have achieved great success in the global market so far, especially some new enterprises. At present, the way multinational companies participate in global competition needs to be changed. In the building of real multinational companies, all the management strategies of multinational companies in the world are in the process of restructuring the value chain and resources, that is, which link in the value chain is controlled, which is finally reflected in the management difference of business process. In view of this, this study is very useful for companies that have gone abroad and are about to go abroad, as well as for companies that are interested in the potential possibility of becoming a mad yo company.

\section{REFERENCES}

[1] Y, Mishchenko, Current trends, foreign economic development strategies, and competitiveness of transnational corporations of Japan, China and Southeast Asia: comparative analysis[J]. RUDN Journal of Economics, 2020, 28(3):465-478.

[2] L Bizikova, G Metternicht, T Yarde, Environmental mainstreaming and policy coherence: essential policy tools to link international agreements with national development - a case study of the Caribbean region[J]. Environment Development \& Sustainability, 2018, 20(3):1-21.

[3] D He, Q Yin, M Zheng, et al, Transport and regional economic integration: Evidence from the Chang-Zhu-Tan region in China[J]. Transport Policy, 2019, 79(JUL.):193-203.

[4] Shushpanov D , Lifanova M . INNOVATIVE 


\section{INSTRUMENTS FOR MANAGING \\ PERSONNEL OF TRANSNATIONAL}

CORPORATIONS[J]. Regional'ni aspekti rozvitku produktivnih sil Ukrani, 2019(24):86-93.

[5] E Carayannis, D Meissner, A Edelkina. Targeted innovation policy and practice intelligence (TIP2E): concepts and implications for theory, policy and practice[J]. The Journal of Technology Transfer, 2017, 42(3):460-484.

[6] O V Kozhevina. Integration of investment strategies in the system of strategic planning of territorial development[J]. Upravlenie, 2019, 7(2):87-94.

[7] J Penca. Transnational environmental regulation and governance: Purpose, strategies and principles; by Veerle Heyvaert | Book review[J]. Governance, 2020, 33(2):453-456.

[8] V Sudakova. The Transcultural Projections of the Strategies of Global Integration of the Contemporary Multicultural Societies[J]. The Culturology Ideas, $2019(15$ (1'2019)):12-28.

[9] A Bulatov. Offshore orientation of Russian Federation FDI[J]. Transnational Corporations, 2017, 24(2):71-89.

[10] C Riccardo, P Carlo, R Roberta. Innovation drivers, value chains and the geography of multinational corporations in Europe[J]. Journal of Economic Geography(6):1053-1086. 